\title{
Membrane Fouling and Chemical Cleaning in Three Full-Scale Reverse Osmosis Plants Producing Demineralized Water
}

\author{
Florian Beyer, ${ }^{1,2}$ Judita Laurinonyte, ${ }^{2}$ Arie Zwijnenburg, ${ }^{2}$ \\ Alfons J. M. Stams, ${ }^{1}$ and Caroline M. Plugge ${ }^{1,2}$ \\ ${ }^{1}$ Laboratory of Microbiology, Wageningen University, Stippeneng 4, 6708 WE Wageningen, Netherlands \\ ${ }^{2}$ Wetsus, European Centre of Excellence for Sustainable Water Technology, Oostergoweg 9, 8911 MA Leeuwarden, Netherlands \\ Correspondence should be addressed to Caroline M. Plugge; caroline.plugge@wur.nl
}

Received 16 December 2016; Revised 16 May 2017; Accepted 18 May 2017; Published 15 June 2017

Academic Editor: Justo Lobato

Copyright (C) 2017 Florian Beyer et al. This is an open access article distributed under the Creative Commons Attribution License, which permits unrestricted use, distribution, and reproduction in any medium, provided the original work is properly cited.

Membrane fouling and cleaning were studied in three reverse osmosis (RO) plants. Feed water was secondary wastewater effluent, river water, and surface water. Membrane autopsies were used for fouling characterization. Fouling layer measurements included total organic carbon (TOC), adenosine triphosphate, polysaccharides, proteins, and heterotrophic plate counts. In all locations, membrane and spacer fouling was (bio)organic. Plant chemical cleaning efficiencies were evaluated from full-scale operational data and cleaning trials in a laboratory setup. Standard cleaning procedures were compared to two cleaning procedures specifically adapted to treat (bio)organic fouling using commercial blend cleaners (mixtures of active substances). The three RO plants were impacted by irreversible foulants causing permanently decreased performance in normalized pressure drop and water permeability even after thorough chemical cleaning. The standard plant and adapted cleaning procedures reduced the TOC by $45 \%$ on average, with a maximum of $\sim 80 \%$. In general, around $20 \%$ higher biomass removal could be achieved with adapted procedure I compared to adapted procedure II. TOC measurements and SEM showed that none of cleaning procedures applied could remove foulants completely from the membrane elements. This study underlines the need for novel cleaning approaches targeting resistant foulants, as none of the procedures applied resulted in highly effective membrane regeneration.

\section{Introduction}

High-pressure driven reverse osmosis (RO) membrane filtration is capable of generating large amounts of ultrapure water for industrial applications. The excellent removal capacity of contaminants, decreasing prices for membranes, and enhanced membrane lifetimes led to widespread acceptance and popularity of RO.

One of the major concerns in the operation of RO plants is reduced membrane performance by fouling. Biofouling, the most common form of membrane fouling, is the type of fouling that is the hardest to control [1-3]. An increase of the normalized feed channel pressure drop (NPD) over the feed spacer channel, a decrease in the normalized specific water permeability $\left(K_{w}\right)$, and/or changes in salt retention are common operational key performance indicators that show fouling development in full-scale applications [3-5]. Rapid biofouling typically manifests in the lead modules of the first stage, causing a strong increase in NPD and moderate decrease in $K_{w}$ [3-5], while slow biofouling may manifest throughout the whole installation [5]. Rarely, biofouling manifests in other parts of the installation, such as the tail elements of the last stage [6].

To overcome the fouling problems, chemical cleaning in place (CIP) is applied to restore the original RO performance in terms of NPD, $K_{w}$, and normalized salt rejection capacity. Generally applied acid-base CIPs often fail to fully restore RO performance and to remove all deposits from the membrane elements $[5,7,8]$. If the membrane performance cannot be restored up to a specifically defined level (e.g., permanently increased NPD by $>15 \%$ after CIP), the RO plant will continuously operate with fouling problems.

CIP efficiencies strongly depend on chemical reactions between foulants and membrane surface, as well as the 
reactions between foulants and chemicals, which include hydrolysis, peptization, saponification, solubilization, dispersion, and chelation [9-11]. There are several categories of cleaning agents such as alkaline solutions, acids, metal chelating agents, surfactants, enzymes, and oxidizing agents. Additionally, commercial blends of chemical active substances are available, but manufacturers often do not reveal the precise composition [10]. Chemical cleaning agents act specifically and the choice of the CIP procedure should depend on the fouling composition of the individual RO plant. Alkaline solutions, for instance, remove organic foulants on membranes through hydrolysis and consecutive solubilization. Metal chelating agents specifically remove divalent cations from complex molecules (e.g., extracellular polymeric substances (EPS)) and as such weaken the structural integrity of the fouling layer matrix. Surfactants solubilize macromolecules by forming micelles around them, thereby facilitating the removal of foulants from the membrane surface [12]. Acid cleaning dissolves scaling [13] and destroys the cell wall integrity of microorganisms and also precipitates proteins. Oxidizing agents, such as hydrogen peroxide, are able to oxidize natural organic matter (NOM), act as biocide [14], and can increase hydrophilicity by increasing the amount of oxygen-containing functional groups such as carboxyl and phenolic groups [15].

Operational parameters such as duration, temperature, shear stress, and pressure also have a significant influence on cleaning efficiency $[10,11,16]$. Short filtration cycles (i.e., more frequent but shorter cleaning procedures) are beneficial, as the fouling layers become more compact with time and become more difficult to remove $[9,17]$. In general, cleaning efficiency increases with temperature, but the heat tolerance of membranes must be considered [18].

In this study, fouling and membrane cleaning was investigated at three full-scale plants producing demineralized water by RO from extensively pretreated feed water. Membrane fouling layers from the three locations were studied and extensively characterized. Efficiencies of full-scale CIP of persistent and harsh fouling layers were evaluated from membrane performance data and during laboratory membrane cleaning experiments. Two (bio)organic fouling specific adapted cleaning procedures (AP I and II), using commercial blend cleaners, were tested and compared with the respective standard plant cleaning procedures $(\mathrm{PP})$ in a laboratory cleaning setup.

The aim of this study was to determine the limitations of conventional chemical cleaning with persistent and harsh bio(organic) fouling layers developed during long-term operation.

\section{Materials and Methods}

2.1. RO Plants Characteristics and Membrane Elements Used. Membrane and spacer materials for this study (Table 1) were taken from fouled spiral-wound membrane elements from three different RO filtration plants producing demineralized water from secondary wastewater effluent, river water, and surface water (RO location I (Sas van Gent, Netherlands), location II (Dordrecht, Netherlands), and location III
(Veendam, Netherlands), resp.). A description and schematic representation of the plant designs and pretreatment can be found in Supplementary data S1 in Supplementary Material available online at https://doi.org/10.1155/2017/6356751. The operational history and specifications of the membrane elements are summarized in Table 1.

2.2. Membrane Cleaning and Performance in Full Scale. Fullscale operational performance data, normalized pressure drop (NPD), normalized specific water permeability $\left(K_{w}\right)$, and normalized salt rejection, were calculated as described by $[7,19]$.

The CIPs applied in all three installations (Table 2) are essentially a high $\mathrm{pH}$ cleaning step followed by a low $\mathrm{pH}$ cleaning step. However, there are differences in the circulation and soaking times. The total duration of the CIPs varies from 6.5 to 24 hours between locations (Table 2). At locations II and III, the low $\mathrm{pH}$ cleaning is performed with a commercial mixed acid detergent, intended to improve foulant solubility. At location III, which has been extensively studied for its biofouling problems [20-23], sodium bisulfite is used during the high $\mathrm{pH}$ cleaning in order to achieve anoxic conditions and improved microbial inactivation. The volumetric flow rate during cleaning at all locations is $9 \mathrm{~m}^{3} \mathrm{~h}^{-1}$ for each membrane vessel in the first stage. However, as location I uses membrane elements with a thicker feed spacer $(34 \mathrm{mil} / 864 \mu \mathrm{m})$ than locations II and III $(28 \mathrm{mil} / 711 \mu \mathrm{m})$ (Table 1), linear flow velocity in the lead membrane element during CIP is lower at location I $\left(0.184 \mathrm{~m} \mathrm{~s}^{-1}\right.$ for location I and $0.202 \mathrm{~m} \mathrm{~s}^{-1}$ for locations II and III) (Table 2).

2.3. Protocol for Chemical Cleaning at Laboratory Scale. Two short ( 3 and 4.5 hours) adapted cleaning procedures (AP I and AP II) with commercial blend cleaners (Table 3) were benchmarked against the individual plant CIP procedures (PP) (Table 2). AP I and AP II protocols are shown in Table 3.

AP I (Table 3) was carried out with low $\mathrm{pH}$ acid, surfactant-based, liquid detergent cleaner ((P3-Ultrasil 73), containing citric acid $(10-<20 \%)$, L-(+)-lactic acid $(5-<10 \%)$, and alkyl-aryl-sulfonic acid $(3-<5 \%)$ ), enzymatic cleaner ((P3-Ultrasil 53) containing unspecified proteases, tetrasodium-EDTA $(\sim 35-<50 \%)$, and phosphates $(20-<30 \%))$, and sanitizing cleaner ((P3-oxonia active) containing acetic acid (8\%), peroxyacetic acid (5.8\%), and hydrogen peroxide $(27.5 \%)$ ). AP II (Table 3 ) was performed with alkaline cleaner ((P3-Ultrasil 110) containing $\mathrm{NaOH}$ (7\%), tetrasodium-EDTA (5-20\%), and benzenesulfonic acid $(2-10 \%))$ and the same acid, surfactant-based, liquid detergent (P3-Ultrasil 73) as in AP I. All information about cleaner compositions was deduced from their respective MSDS datasheets.

2.4. High-Pressure Test Cell. A flat sheet high-pressure crossflow cell (University of Twente, Netherlands), consisting of two stainless steel metal plates, was used for the laboratory experiments. Flow chamber spatial dimensions were $w \cdot l \cdot h=12.7 \mathrm{~cm} \cdot 19.8 \mathrm{~cm} \cdot 0.3 \mathrm{~cm}$. Flow channel height was adjusted to the respective spacer thickness 
TABLE 1: Specification and operational history of the membrane elements used in this study.

\begin{tabular}{lccc}
\hline Location & $\begin{array}{c}\text { Location I } \\
\text { Sas van Gent, Netherlands }\end{array}$ & $\begin{array}{c}\text { Location II } \\
\text { Dordrecht, Netherlands }\end{array}$ & $\begin{array}{c}\text { Location III } \\
\text { Veendam, Netherlands }\end{array}$ \\
\hline Feed water & Secondary waste water effluent & River water & Surface water \\
Membrane element & DOW FILMTEC & DOW FILMTEC LE-440i & DOW FILMTEC LE-440i \\
Membrane configuration \& type & Spiral wound thin-film composite & Spiral wound thin-film composite & Spiral wound thin-film composite \\
Spacer thickness [mil $/ \mu \mathrm{m}]$ & $34 / 864$ & $28 / 711$ & $28 / 711$ \\
Active membrane area $\left[\mathrm{m}^{2}\right]$ & 37 & 41 & 41 \\
CIP frequency [per year] & $\sim 17$ per year & $\sim 17$ per year & $\sim 7$ per year \\
Days of operation [elements] & $644 / 652^{\mathrm{a}}$ & 1056 & 1057 \\
Days since last CIP & $33 / 2^{\mathrm{a}}$ & 15 & 20 \\
\hline
\end{tabular}

$1 \mathrm{mil}=0.001 \mathrm{inch}=25.4 \mu \mathrm{m} .{ }^{\mathrm{a}}$ From this installation, two membrane elements were autopsied, one before last full-scale CIP and one after last full-scale CIP.

TABLE 2: Chemical cleaning in place (CIP) procedures applied at the three locations studied.

\begin{tabular}{|c|c|c|c|}
\hline Location & $\begin{array}{c}\text { Location I } \\
\text { Sas van Gent, Netherlands }\end{array}$ & $\begin{array}{c}\text { Location II } \\
\text { Dordrecht, Netherlands }\end{array}$ & $\begin{array}{c}\text { Location III } \\
\text { Veendam, Netherlands }\end{array}$ \\
\hline Linear flow velocity & $0.184 \mathrm{~m} \mathrm{~s}^{-1}$ & $0.202 \mathrm{~m} \mathrm{~s}^{-1}$ & $0.202 \mathrm{~m} \mathrm{~s}^{-1}$ \\
\hline Feed pressure & 1 bar & 1 bar & 1 bar \\
\hline Total duration & 8 hours & 24 hours & 6.5 hours \\
\hline Step 1 & $\begin{array}{l}\text { Circulation with } \mathrm{NaOH} \\
60 \mathrm{~min} ; T=35^{\circ} \mathrm{C} ; \mathrm{pH}=12\end{array}$ & $\begin{array}{c}\text { Circulation with } \mathrm{NaOH} \\
120 \text { min; } T=35^{\circ} \mathrm{C} ; \mathrm{pH}=12\end{array}$ & Prerinsing with demi water \\
\hline Step 2 & $\begin{array}{c}\text { Soaking with } \mathrm{NaOH} \\
30 \mathrm{~min} ; T=35^{\circ} \mathrm{C} ; \mathrm{pH}=12\end{array}$ & $\begin{array}{l}\text { Soaking (overnight) with } \mathrm{NaOH} \\
T=20^{\circ} \mathrm{C} ; \mathrm{pH}=12\end{array}$ & $\begin{array}{l}\text { Soaking with demi water } \\
\qquad 30 \mathrm{~min}\end{array}$ \\
\hline Step 3 & $\begin{array}{l}\text { Circulation with } \mathrm{NaOH} \\
60 \mathrm{~min} ; \mathrm{T}=35^{\circ} \mathrm{C} ; \mathrm{pH}=12\end{array}$ & Rinsing with demi water & $\begin{array}{l}\mathrm{NaHSO}_{3} ; \mathrm{pH}=10.5 \text { (adjust } \mathrm{pH} \\
\text { with } \mathrm{NaOH} \text { ) } \\
60 \mathrm{~min} ; \mathrm{T}=35^{\circ} \mathrm{C} ; \mathrm{C}=1-1.5 \% \mathrm{v} / \mathrm{v}\end{array}$ \\
\hline Step 4 & $\begin{array}{c}\text { Soaking with } \mathrm{NaOH} \\
30 \mathrm{~min} ; \mathrm{T}=35^{\circ} \mathrm{C} ; \mathrm{pH}=12\end{array}$ & $\begin{array}{l}\text { Circulation with Divos } 2 \\
90 \mathrm{~min} ; \mathrm{T}=35^{\circ} \mathrm{C} ; \mathrm{pH}=1.6\end{array}$ & $\begin{array}{c}\text { Soaking with } \mathrm{NaHSO}_{3} \\
120 \mathrm{~min} ; \mathrm{T}=20^{\circ} \mathrm{C} ; \mathrm{pH}=10.5\end{array}$ \\
\hline Step 5 & $\begin{array}{l}\text { Circulation with } \mathrm{NaOH} \\
60 \mathrm{~min} ; T=35^{\circ} \mathrm{C} ; \mathrm{pH}=12\end{array}$ & Final rinsing with demi water & Rinsing with demi water \\
\hline Step 6 & $\begin{array}{c}\text { Soaking with } \mathrm{NaOH} \\
30 \mathrm{~min} ; \mathrm{T}=35^{\circ} \mathrm{C} ; \mathrm{pH}=12\end{array}$ & & $\begin{array}{c}\text { Divos } 2 \\
30 \mathrm{~min} ; \mathrm{T}=35^{\circ} \mathrm{C} ; \mathrm{pH}=2.5\end{array}$ \\
\hline Step 7 & Rinsing with demi water & & $\begin{array}{l}\text { Soaking with Divos } 2 \\
60 \mathrm{~min} ; \mathrm{T}=20^{\circ} \mathrm{C} ; \mathrm{pH}=2.5\end{array}$ \\
\hline Step 8 & $\begin{array}{c}\text { Circulation with } \mathrm{HCl} \\
60 \mathrm{~min} ; T=35^{\circ} \mathrm{C} ; \mathrm{pH}=2.1\end{array}$ & & Final rinsing with demi water \\
\hline Step 9 & $\begin{array}{c}\text { Soaking with } \mathrm{HCl} \\
30 \mathrm{~min} ; \mathrm{T}=35^{\circ} \mathrm{C} ; \mathrm{pH}=2.1\end{array}$ & & \\
\hline Step 10 & $\begin{array}{c}\text { Circulation with } \mathrm{HCl} \\
60 \mathrm{~min} ; \mathrm{T}=35^{\circ} \mathrm{C} ; \mathrm{pH}=2.1\end{array}$ & & \\
\hline Step 11 & $\begin{array}{c}\text { Soaking with } \mathrm{HCl} \\
30 \mathrm{~min} ; \mathrm{T}=35^{\circ} \mathrm{C} ; \mathrm{pH}=2.1\end{array}$ & & \\
\hline Step 12 & Final rinsing with demi water & & \\
\hline
\end{tabular}

demi water $=$ dimineralized water (RO permeate); Divos 2 = mixed acid detergent descaler (JohnsonDiversey, UK).

(Table 1) with solid plastic spacers. Permeate is collected through a porous aluminum sintered plate. Feed water is distributed by a cylindrical flow distribution channel and concentrate is collected in similar manner. Separate channels at feed and concentrate side are used to measure the feed-concentrate pressure drop. The flow cell was successfully employed in previous biofouling studies [22, 23].
2.5. High-Pressure Filtration Setup. A high-pressure laboratory filtration setup (Supplementary Figure S2.1) was used to determine key performance indicators, water permeability $\left(K_{w}\right)$, feed-concentrate channel pressure drop (FCP), and salt rejection capacity.

The setup is operated at constant pressure and flow; thus permeability decrease is detected by reduced permeate flow. The setup is fed with cartridge filtered (Borso-Spun 
TABLE 3: CIP procedures for (bio)organic fouling removal at laboratory scale.

\begin{tabular}{|c|c|c|}
\hline & Adapted procedure (AP) I & Adapted procedure (AP) II \\
\hline Feed pressure & 1 bar & 1 bar \\
\hline Total duration & 4.5 hours & 3 hours \\
\hline Step 1 & Prerinsing with demi water & Prerinsing with demi water \\
\hline Step 2 & $\begin{array}{c}\text { Acid, P3-Ultrasil } 73 \\
45 \mathrm{~min} ; T=45^{\circ} \mathrm{C} ; C=1.5 \% \mathrm{v} / \mathrm{v} ; \mathrm{pH}=2.5\end{array}$ & $\begin{array}{c}\text { Alkaline, P3-Ultrasil } 110 \\
30 \mathrm{~min} ; \mathrm{T}=30^{\circ} \mathrm{C} ; \mathrm{C}=1.5 \% \mathrm{v} / \mathrm{v} ; \mathrm{pH}=12.1-12.3\end{array}$ \\
\hline Step 3 & Rinsing with demi water & Rinsing with demi water \\
\hline Step 4 & $\begin{array}{c}\text { Neutral, P3-Ultrasil } 53 \\
90 \mathrm{~min} ; \mathrm{T}=37^{\circ} \mathrm{C} ; \mathrm{C}=1.5 \% \mathrm{w} / \mathrm{v} ; \mathrm{pH}=9.6-10\end{array}$ & $\begin{array}{c}\text { Acid, P3-Ultrasil } 73 \\
30 \mathrm{~min} ; T=45^{\circ} \mathrm{C} ; C=1 \% \mathrm{v} / \mathrm{v} ; \mathrm{pH}=2.5\end{array}$ \\
\hline Step 5 & $\begin{array}{c}\text { Neutral, P3-Ultrasil } 53 \\
30 \mathrm{~min} ; \mathrm{T}=30-45^{\circ} \mathrm{C} ; \mathrm{C}=4 \% \mathrm{w} / \mathrm{v} ; \mathrm{pH}=8-10\end{array}$ & Rinsing with demi water \\
\hline Step 6 & Rinsing with demi water & $\begin{array}{c}\text { Alkaline, } \mathrm{P} 3-\text { Ultrasil } 110 \\
30 \mathrm{~min} ; \mathrm{T}=35^{\circ} \mathrm{C} ; \mathrm{C}=0.8 \% \mathrm{v} / \mathrm{v} ; \mathrm{pH}=11.6-11.8\end{array}$ \\
\hline Step 7 & $\begin{array}{c}\text { Sanitizing, P3-oxonia active } \\
60 \mathrm{~min} ; T_{\max }=25^{\circ} \mathrm{C} ; \mathrm{C}=1 \% \mathrm{v} / \mathrm{v}\end{array}$ & Final rinsing with demi water \\
\hline Step 8 & Final rinsing with demi water & \\
\hline
\end{tabular}

demi water $=$ dimineralized water.

PP $10 \mu \mathrm{m}$, Van Borselen Filters B.V., Zoetermeer, Netherlands) drinking water from a buffer tank. A frequency controlled high-pressure pump (Hydra-Cell ${ }^{\mathrm{TM}}$ pump, Wanner Engineering Inc., Minneapolis, USA) is used to pressurize the feed water to 6 bar. Constant pressure is achieved using a pressure controller (EL-PRESS, P-702C-AGB-020A, digital pressure meter/controller, Bronkhorst High-Tech, Ruurlo, Netherlands), located in a bypass over the highpressure feed pump. Stable flow is maintained using a flow controller (CORI-FLOW, M55C4-AGD-44-K-C, digital mass flow meter/controller, Bronkhorst High-Tech, Ruurlo, Netherlands). Feed-concentrate channel pressure drop is assessed with an accurate differential pressure meter Cerabar T, 0-500 mbar (+/-0.1 mbar) (Endress+Hauser, Reinach, Switzerland). Permeate production is measured using a flow meter (LIQUI-FLOW, L23-AGB-33-0, digital mass flow meter, Bronkhorst High-Tech, Ruurlo, Netherlands). All data is registered and stored using a data logger (RSG30, Endress+Hauser, Reinach, Switzerland)

2.6. Data Normalization from Laboratory-Scale Cleaning Experiments. FCP was directly measured. Water permeability $\left(K_{w}\right)$ and water flux $\left(J_{w}\right)$ were derived as described in [24]. During the experiments, temperature was maintained at $20^{\circ} \mathrm{C} . K_{w}, \mathrm{FCP}$, and salt rejection cleaning efficiencies are presented as \% improvement.

2.7. Membrane Cleaning Setup. A low-pressure setup (Supplementary Figure S2.2) was used to perform the chemical cleaning experiments on laboratory scale. The cleaning setup consists of a thermo-controlled vessel (JULABO P $1000 \mathrm{~W}$ and JULABO VC $1050 \mathrm{~W}$, Juchheim Labortechnik KG, Seelbach/West Germany) containing $8 \mathrm{~L}$ of cleaning agent. The cleaning agent is pumped into the test cell using a high velocity peristaltic pump (Masterflex L/S pumps, ColePalmer Instrument Company, Vernon Hills, Illinois, USA). A manometer is placed between the pump and the test cell.
During chemical cleaning, permeate production is prevented by blocking the permeate channel outlet. Cleaning agent is filtered using a $10 \mu \mathrm{m}$ pore size cartridge filter (BorsoSpun PP $10 \mu \mathrm{m}$, Van Borselen Filters BV, Zoetermeer, Netherlands) to reject removed foulants, before being recycled to the cleaning vessel. Flow is adjusted using a manual flow controller (Brooks 8805, Brooks Instrument, Hatfield, USA). Temperature is measured using a PT 100 temperature sensor (S + S Regeltechnik GmbH, Nürnberg, Germany).

2.8. Cleaning Procedures and Assessment of Cleaning Effectiveness. Chemical cleaning studies were performed in the laboratory membrane cleaning setup (Supplementary Figure S2.2) with fouled sheets of membrane and spacer material from full-scale operation. The fouled membrane elements were autopsied as described by [7] and sheets of fouled membrane and spacer material were cut and stored in tap water at $4^{\circ} \mathrm{C}$ for cleaning experiments.

Cleaning efficiencies of the fouled membrane and spacer sheets were assessed using the key performance indicators FCP, $K_{w}$, and salt rejection and deposit measurements such as total organic carbon (TOC), adenosine triphosphate (ATP), colony-forming units (CFU), scanning electron microscopy (SEM), and energy dispersive X-ray spectroscopy (EDS) measurements.

For fouling characterization of the full-scale membrane elements, protein and polysaccharide quantification was applied in addition to TOC, ATP, CFU, SEM, and EDS measurements.

Key performance indicators FCP, $K_{w}$, and salt rejection were assessed using the high-pressure filtration setup.

2.9. Analytical Methods. TOC, ATP, SEM, and EDS measurements were performed as described by [7].

For protein and polysaccharide quantification, biofilms were harvested and homogenized as described in [24]. Homogenates were subsequently centrifuged at $3,000 \times \mathrm{g}$ 


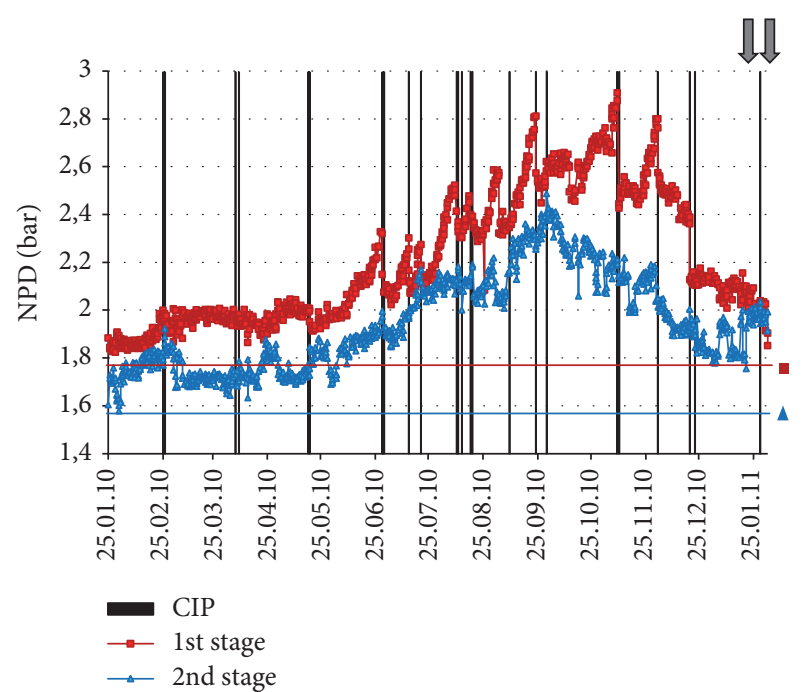

(a)

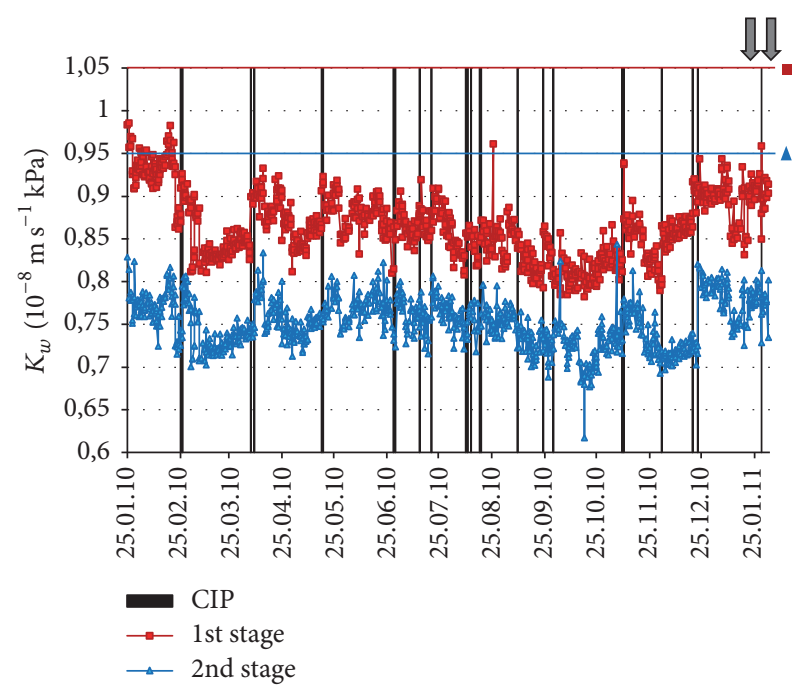

(b)

FiguRE 1: Key performance parameters NPD (a) and $K_{w}$ (b) of plant location I. Vertical lines indicate CIP. Horizontal lines indicate performance with new membranes [day zero]. From this installation, a lead element from the first stage was taken before (25.01.2011) and directly after the last CIP indicated (02.02.2011). Time points of membrane autopsies are indicated with dark grey arrows.

for $10 \mathrm{~min}$, at room temperature, to remove debris. Protein concentration and polysaccharide concentrations in the supernatant were then determined as described by [24].

Bacterial cell counts were performed using a CFU measurement. Biomass was scraped off the membrane $(\sim$ $15-20 \mathrm{~cm}^{2}$ surface area) and dissolved in $1-1.5 \mathrm{~mL}$ of PBS. The sample was then homogenized using vortex mixing, before serial dilutions $\left(10^{-1}\right.$ to $\left.10^{-7}\right)$ were prepared. Dilutions $10^{-4}$ to $10^{-7}$ were plated in duplicate on R2A agar plates (Difco). Plates were standing upright for $30 \mathrm{~min}$ and then were incubated upside down at $25^{\circ} \mathrm{C}$ for 7 days. Colonies were counted according to ISO 8199 . CFU per $\mathrm{cm}^{2}$ membrane area was then calculated.

\section{Results and Discussion}

\subsection{Full-Scale Operation: Effect of Fouling on Performance (NPD and $K_{w}$ ) and CIP Efficiencies}

Location I (Sas van Gent, Netherlands). Fouling causes increased NPD and decreased $K_{w}$ in both stages of the installation (Figure 1). Starting in summer, NPD increases rapidly in both stages, and while $K_{w}$ can be kept stable with CIPs applied, it is permanently reduced ( - $10 \%$, first stage; $-15 \%$, second stage). The rapid increase in NPD and decrease in $K_{w}$ in the summer and autumn months (Figure 1) are likely due to the increased temperature of the effluent during this period. The cleaning frequency was 17 times in one year (Figure 1 and Table 1). In summer months, the conventional CIPs applied do not restore the NPD and, after several CIPs, NPD increases to about 30-40\% (Figure 1) of day zero values.

Two lead elements from the first stage, one before last fullscale CIP and one after the last full-scale CIP, were autopsied for fouling analyses and to evaluate representativeness of the laboratory cleaning setup. At the time of membrane autopsies for cleaning studies (before last CIP applied in Figure 1), NPD was increased in both stages $(\sim+10 \%$, first stage, and $\sim+25 \%$, second stage) and $K_{w}$ was reduced in both stages ( $-15 \%$, first stage, and $\sim-20 \%$, second stage). The last CIP applied resulted in some reduction in NPD in the first stage, while NPD in the second stage and $K_{w}$ in both stages were not affected much (Figure 1).

Location II (Dordrecht, Netherlands). Fouling causes a strong increase in NPD in the first stage and $K_{w}$ reductions in the plant during the summer months (Figure 2) and cleaning frequency was 17 times in one year (Figure 2 and Table 1). At this location, $K_{w}$ is not determined separately for the first and second stages but only as overall plant $K_{w}$. Looking at the NPD and CIP efficiencies data from both stages (Figure 2), the overall plant $K_{w}$ reduction is expected to originate mainly from the NPD increase in the first stage. NPD in the first stage and $K_{w}$ are affected by rapid fouling especially in the summer and autumn months, requiring more frequent cleaning. In the winter and spring months, NPD increase and $K_{w}$ decrease are slower and can be kept relatively stable with the CIPs applied (Figure 2). In general, the CIPs applied were only partly effective, causing the installation to operate constantly with reduced $K_{w}$ and increased NPD in the first stage.

A lead element from the first stage was autopsied for fouling analyses and laboratory cleaning experiments. At the moment of the membrane autopsies, NPD was strongly increased $(\sim+50 \%)$ in the first stage and the overall plant $K_{w}$ was reduced substantially ( $-30 \%)$.

Location III (Veendam, Netherlands). Fouling is characterized by strong NPD increase in the second stage and a temporary $K_{w}$ decrease, which is stronger in the second stage (Figure 3). NPD and $K_{w}$ are affected by rapid fouling especially in 


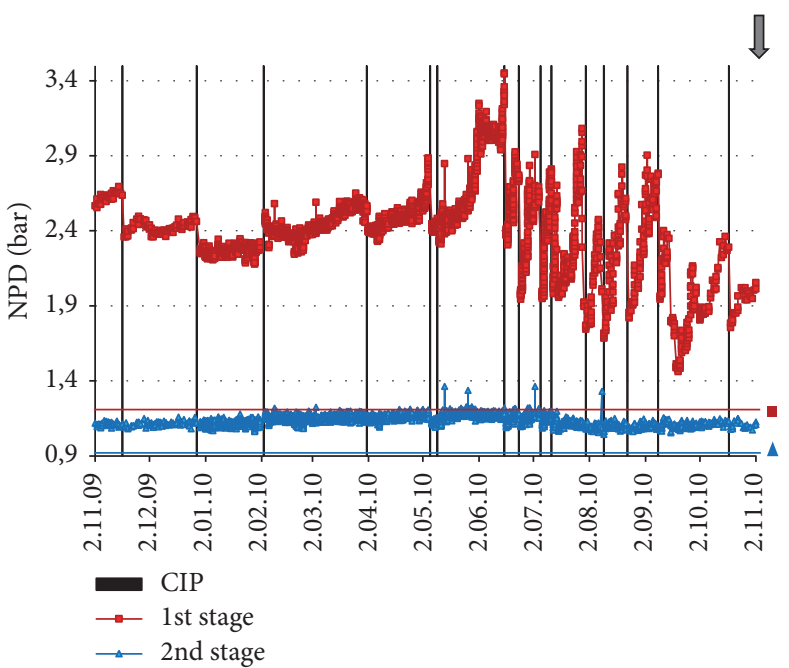

(a)

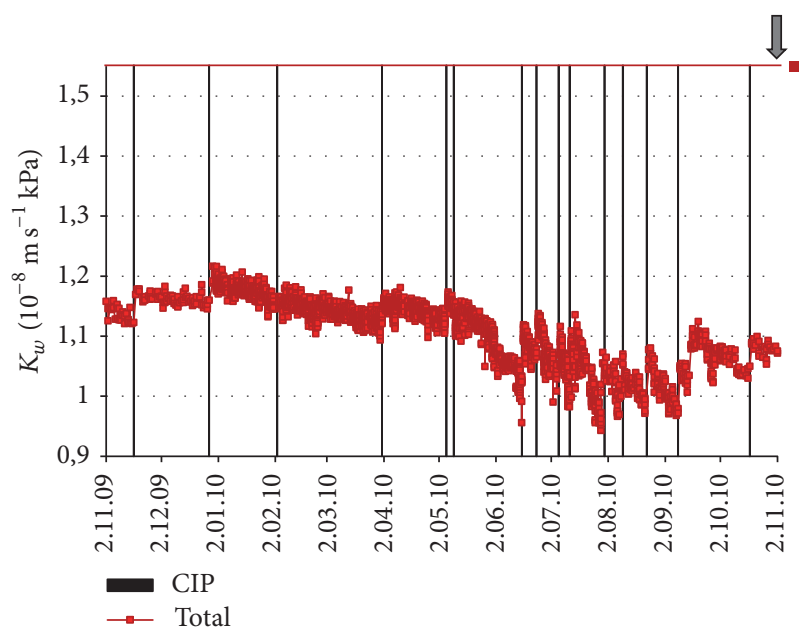

(b)

FIgURE 2: Key performance parameters NPD (a) and $K_{w}$ (b) of plant location II. Vertical lines indicate CIP. Horizontal lines indicate performance with new membranes [day zero]. From this installation, a lead element from the first stage was taken (02.11.2010). Time point of membrane autopsy is indicated with dark grey arrow.

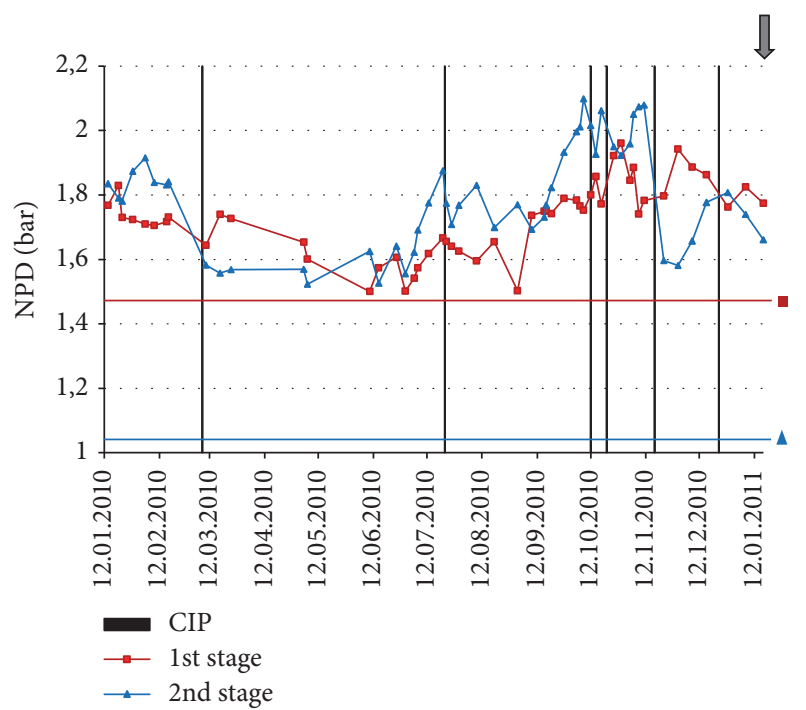

(a)

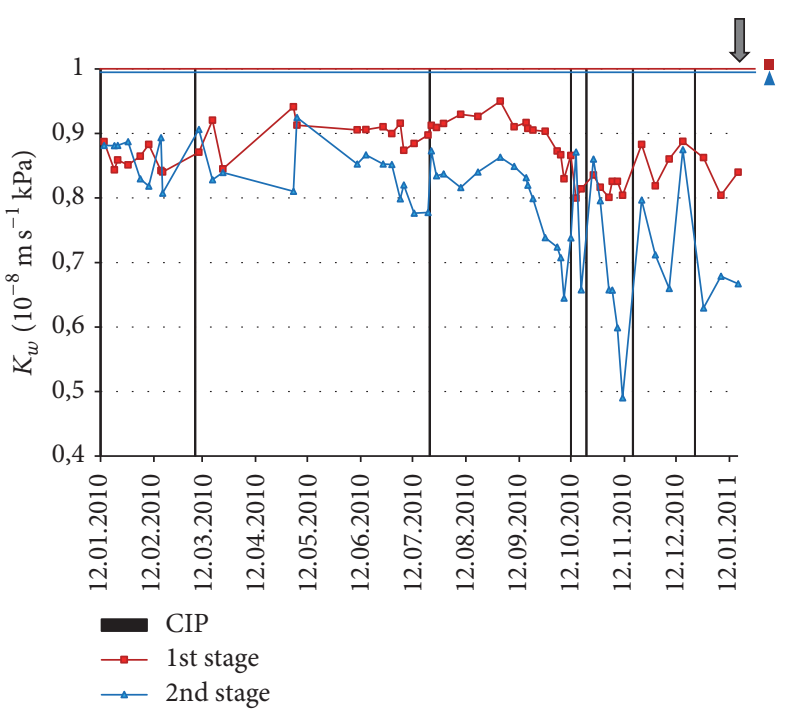

(b)

FIGURE 3: Key performance parameters NPD (a) and $K_{w}$ (b) of plant location III. Vertical lines indicate CIP. Horizontal lines indicate performance with new membranes [day zero]. From this installation, a lead element from the first stage was taken (12.01.2011). Time point of membrane autopsy is indicated with dark grey arrow.

the summer and autumn months, requiring more frequent cleaning. In the winter and spring months, NPD increase and $K_{w}$ decrease are less rapid and can be kept relatively stable with the CIPs applied (Figure 3). Increased NPD in the second stage is main reason for CIPs applied, leading to a cleaning frequency of seven times in one year (Figure 3 and Table 1). CIPs applied (Table 2) are only partly effective, causing the installation to operate constantly with reduced $K_{w}$ and increased NPD in the second stage of the installation.

A lead element from the first stage was autopsied for fouling analyses and laboratory cleaning experiments. At the moment of the membrane autopsies, NPD $(\sim+20 \%)$ and $K_{w}(\sim-15 \%)$ values in the first stage were only moderately affected (Figure 3).

The conventional CIPs applied (Table 2) were not successful under all circumstances, especially during summer months (Figures 1-3). The efficiency of CIPs applied differed from case to case (Figures 1-3), indicating that cleaning efficiency cannot always be predicted from previous experience. This could likely be due to, for example, seasonal changes in the fouling layers and changes in feed water quality when processing, for example, industrial wastewater. All 


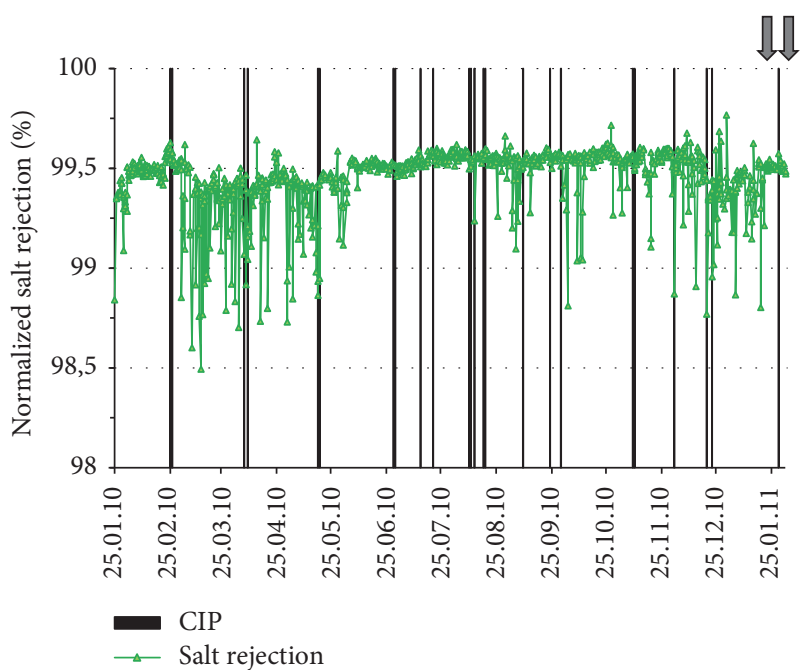

(a)

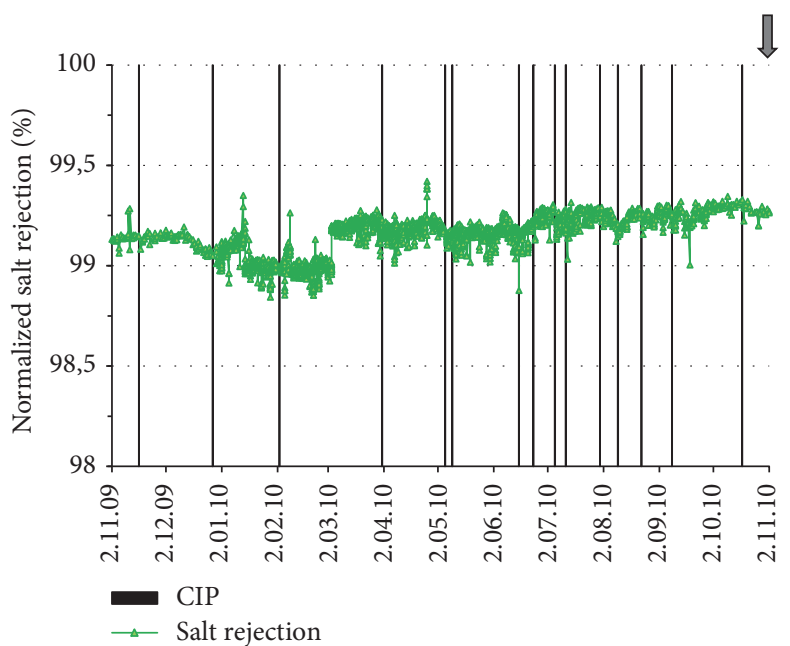

(b)

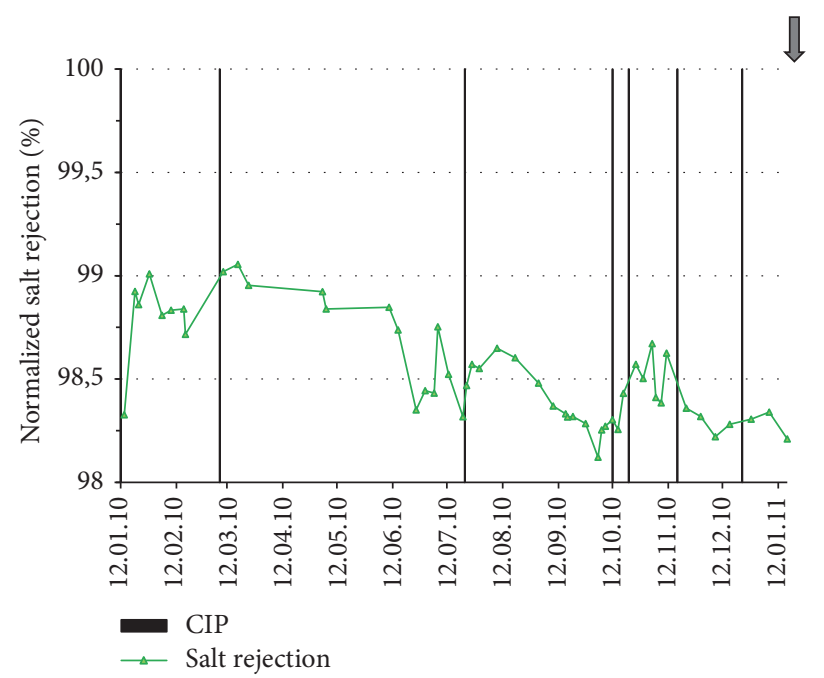

(c)

FIGURE 4: Membrane integrity as indicated by \% salt rejection (= 100 - salt passage) for (a) plant location I, (b) plant location II, and (c) plant location III. Vertical lines indicate CIP. Time points of membrane autopsies are indicated with dark grey arrows.

installations permanently operate suboptimally (Figures 1-3). Foulants that could not be removed by previous conventional CIPs (day zero performance is indicated by horizontal lines in Figures 1-3) had been built up after extended periods of operation $(644,1056$, and 1057 days (Table 1) in locations I, II, and III, resp.).

\subsection{Full-Scale Operation: Effect of CIP on Membrane Integrity} (Salt Rejection). The chemical resistance of the membranes (illustrated by the free chlorine resistance $<0.1 \mathrm{ppm}$, Supplementary Table S4) limits some of the cleaning parameters (e.g., choice of the cleaning agent, concentration, and temperature). Oxidative damage by single or repetitive harsh CIPs will lead to decreased salt rejection of the membranes. Oxidative damage was diagnosed in $~ 15 \%$ (severe damage) to $\sim 50 \%$ (slight damage) of all membranes analyzed in a big study of 500 autopsied membrane elements [3]. All three plants produce demineralized water and therefore membrane integrity as indicated by stable and high salt rejection is a key performance parameter. The effects of the CIP on overall normalized salt rejection of the three locations are illustrated in Figures 4(a)-4(c).

At location I, normalized salt rejection is relatively stable at about $99.5 \%$. Some of the CIPs have a slightly negative effect on normalized salt rejection, but this effect does not seem to be permanent (Figure 4(a)). At location I, the CIPs applied do not have a negative effect on membrane integrity.

At plant location II, normalized salt rejection was largely unaffected by fouling or CIP in the last 8 months before membrane autopsies (Figure 4(b)). Only in January and February (before sampling), salt rejection was about $0.25 \%$ lower which was restored in March. The effect could not be deduced from the $K_{w}$ measurements and remains unexplained.

At location III, normalized salt rejection is unstable and decreases throughout the year by about $0.7 \%$. It is not clear from Figure $4(\mathrm{c})$ whether the decreased normalized salt 
rejection is due to the CIPs applied or other factors such as ageing of the membranes. However, membrane age is similar to location II (Table 1) and if normalized salt rejection drops below 98\%, membrane replacement may be unavoidable at location III.

3.3. Membrane Fouling Characterization by Membrane Autopsies of Full-Scale Membrane Elements. (Bio)organic material was the major foulant found during the fouling layer analyses by EDS in all installations studied. Inorganic compounds were typically below 0.6 atom $\%$ in all samples analyzed. A representative EDS spectrum with related elemental analyses of locations I, II, and III can be found in Supplementary data S3. The (bio)organic origin of the fouling layers could already be deduced from the observations made during autopsies, when fouling layers could be removed by soft mechanical force leaving a smooth membrane surface. An inorganic precipitation or scaling layer in contrast would reveal a sandpaper-like structure on the membrane surface. Furthermore, at location III, biofouling was reported in earlier studies and several biofouling key studies were performed at this location [20-23]. To differentiate between organic fouling and biological fouling, TOC, polysaccharides, proteins, and CFU measurements (Figure 5) and SEM were performed.

TOC values in this study $\left(45.5,22.6\right.$, and $23.5 \mu \mathrm{g} \mathrm{cm}^{-2}$ for locations I, II, and III, resp.) are in the low-to-medium range when compared to literature values $\left(5-150 \mu \mathrm{g} \mathrm{cm}^{-2}\right.$ [7]). Compared to ATP literature values $\left(4-102.000 \mathrm{pg} \mathrm{cm}^{-2}\right.$ ) [7, 25-27], all values measured in this study were low. Location II, which had the highest ATP in this study, also had the highest measured polysaccharides concentration and CFU plate counts (Figure 5). Biofouling is a major type of fouling at this location, which was confirmed by SEM observations (data not shown) showing microorganisms embedded in a polymeric matrix. Location III, very frequently associated with biofouling problems [20-23], showed no CFU plate counts and ATP concentrations were very low (Figure 5). However, 20 days prior to membrane autopsy, an emergency CIP (Table 1 and Figure 3) with oxalic acid had to be performed due to a leak in the UF system (Supplementary Figure S1.3), which possibly explains the very low biomass parameters. At location I with the highest TOC values measured, ATP, protein, and polysaccharide concentrations were low (Figure 5). SEM observations showed microorganisms embedded in an organic matrix (data not shown), which was supported by the CFU counts (Figure 5). For location I, fouling consisted of organic and biological deposits. Based on ATP, protein, and polysaccharide concentrations, fouling in all autopsied membrane elements can be characterized as mild to moderate [27].

3.4. Validation of Laboratory-Scale Cleaning Setup. To validate the representativeness of the laboratory cleaning setup and high-pressure setup, bio(organic) fouling reduction (TOC, ATP, and CFU) during full-scale CIP was compared to cleaning efficiencies achieved during laboratory cleaning for location I, using the standard plant procedure (Table 2). Full-scale cleaning efficiency (Figure 6) was determined by membrane autopsy of a lead element before CIP and autopsy of a lead membrane element after CIP (Figure 1). Sheets of the lead element before CIP were then cleaned in the laboratory membrane cleaning setup to evaluate laboratoryscale cleaning efficiency (Supplementary Figure S2.2).

During full-scale CIP, TOC reduction was $67 \pm 19 \%$ as opposed to $33 \pm 19 \%$ in the laboratory setup. ATP reduction was $70 \pm 10 \%$ for full-scale CIP and $93 \pm 5 \%$ for laboratoryscale cleaning (Figure 6). CFU counts were reduced to zero in both full-scale and laboratory-scale CIPs.

Cleaning efficiencies in terms of TOC and ATP reduction were somewhat dissimilar (Figure 6), but deviation must also be taken into account. The membrane elements from full-scale cleaning before and after CIP originated from two different pressure vessels, while laboratory-scale cleaning was performed on a single sheet, causing some deviation of the results. Moreover, the membrane elements from full-scale cleaning were sampled over the whole length $(1 \mathrm{~m})$, while for cleaning experiments in the laboratory, only membrane and spacer samples from the first $30 \mathrm{~cm}$ of the full-scale membrane elements were used. Fouling is not distributed evenly over membrane elements or single membrane envelopes, causing deviation when comparing samples from different membrane envelops of the same membrane element. However, the trends were consistent. SEM-EDS observations (Supplementary data S3, SEM not shown) and visual observations after full-scale and laboratory-scale CIPs were also more consistent.

It was concluded that cross-flow filtration test cells offer good representation of the complex physical interactions, when, for example, compared to simple static cleaning tests using model foulants. Although not 1:1 translatable into fullscale operation, the laboratory cleaning setup using crossflow cells can be a useful tool for comparative testing of cleaning chemicals and CIP procedures of full-scale membrane elements.

\subsection{Comparative CIPs with Alternative \\ Procedures on Laboratory Scale}

3.5.1. Effect of Cleaning on Membrane Integrity (Salt Rejection). Salt rejection is a key performance parameter during the production of ultrapure water by RO. For the respective plant procedures and alternative procedure AP II, no significant changes in salt rejection could be observed for all three locations (Figure 7). For AP I, salt rejection increased in all three locations ( 0.25 to $0.6 \%)$.

There are temporal or permanent interactions of cleaners with the fouling layers and membrane properties. The missing $\mathrm{NaOH}$ cleaning step in AP I may explain the observed increase in salt rejection for this procedure (membrane shrinking by low $\mathrm{pH}$ cannot be restored by a high $\mathrm{pH}$ cleaning step).

The comparative cleaning experiments performed under laboratory-scale conditions showed no negative effect on membrane integrity as indicated by stable salt rejection (Figures 7 and 10). After all, oxidative damage after repetitive CIPs with the alternative procedures (Table 3) cannot be excluded but seems unlikely. 


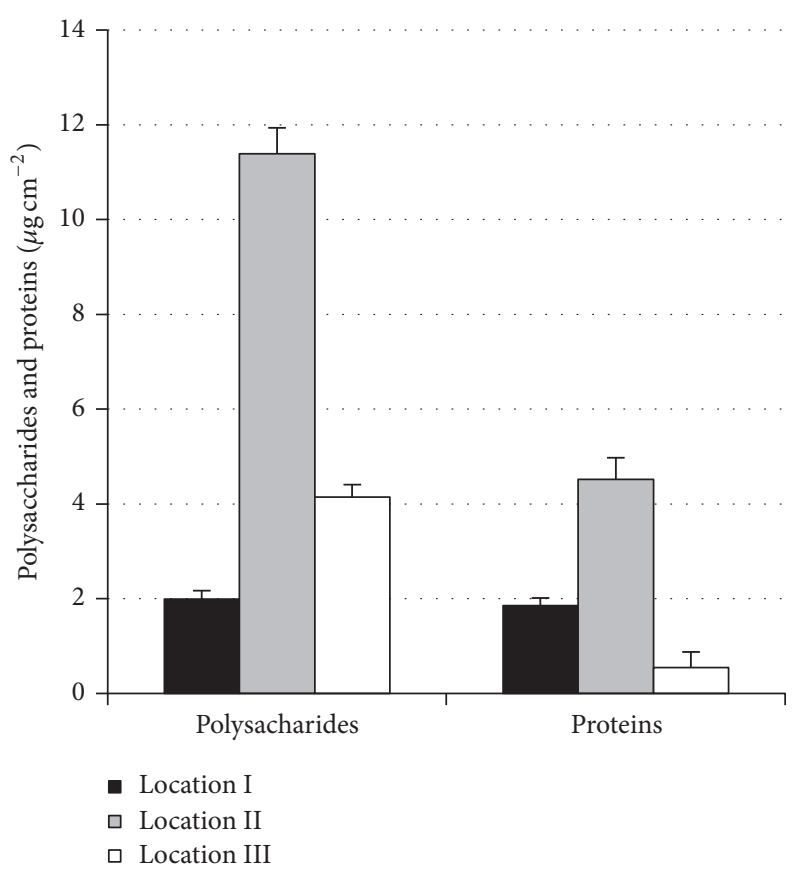

(a)

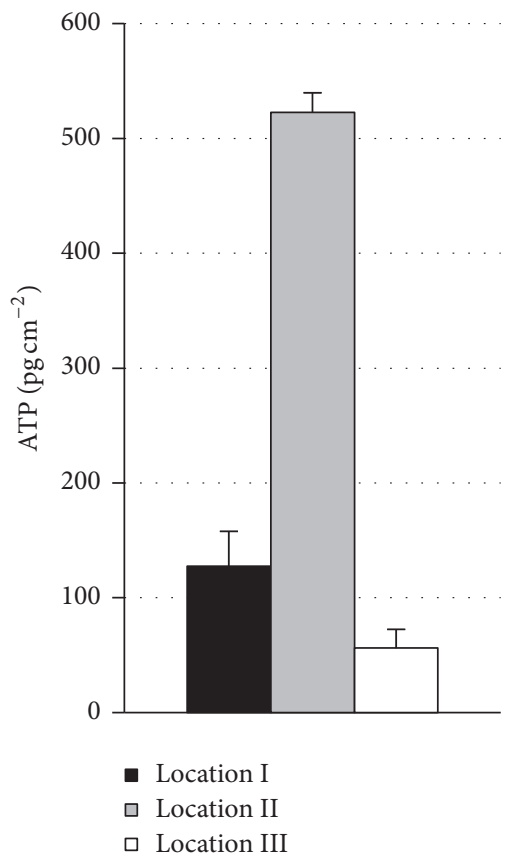

(c)

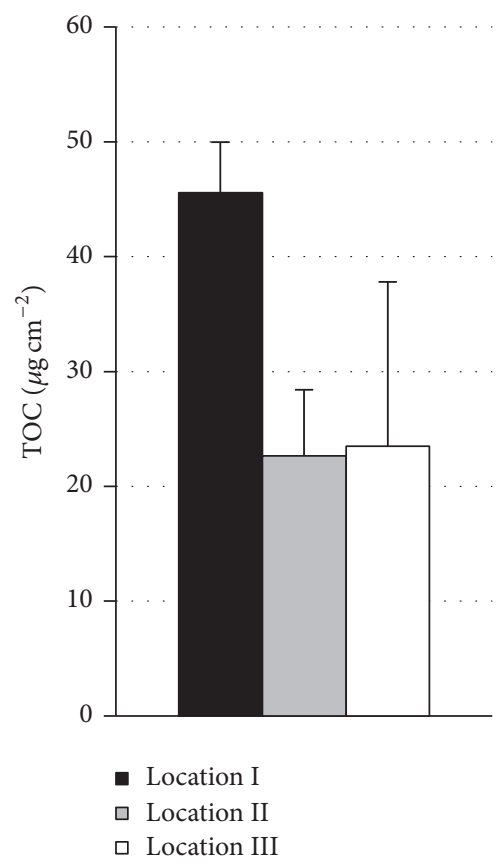

(b)

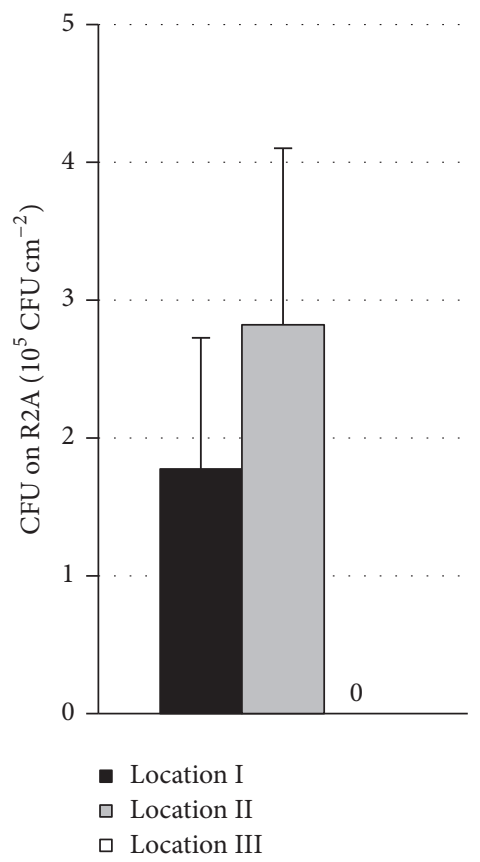

(d)

FIGURE 5: Fouling characterization from membrane and spacer samples from three RO locations studied. From (a)-(d), polysaccharides and proteins, total organic carbon, adenosine triphosphate, and colony-forming units on R2A agar.

3.5.2. (Bio)organic Fouling Parameters (ATP and TOC) before and after Laboratory-Scale Cleaning. Figure 8 shows TOC and ATP removal after laboratory cleaning, with the respective standard plant cleaning procedures (Table 2) and the two adapted cleaning procedures (Table 3 ) for location I, location II, and location III $(n \geq 2)$. None of the CIPs applied (standard plant procedures and AP I and AP II) (Tables 2 and 3) was able to remove all TOC from the membrane and spacer samples (Figure 8 ). Average TOC reduction was approximately 45\% ( 20-80\%) (Figure 8).

It is worth noting that AP I (Table 3), which ends with a sanitizing step using a biocidal cleaner (acetic acid (8\%), peroxyacetic acid (5.8\%), and hydrogen peroxide $(27.5 \%)$ as active ingredients), showed the lowest efficiencies in 


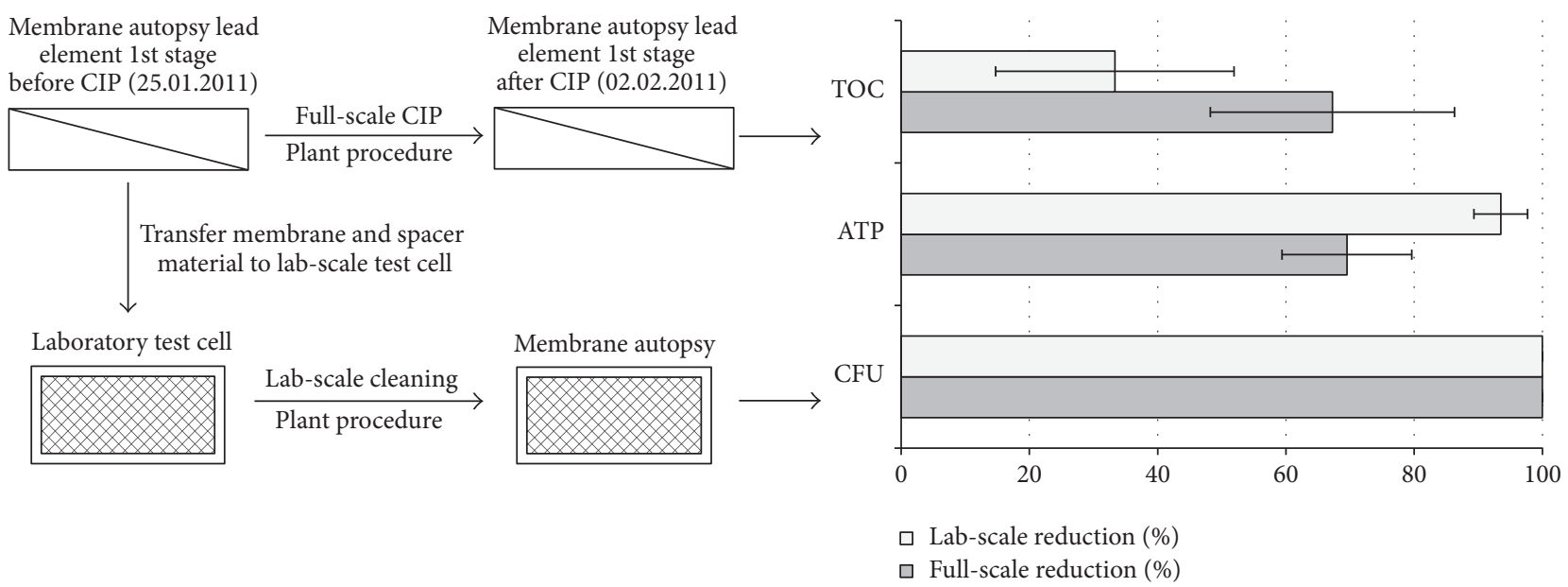

FIGURE 6: Laboratory cleaning setup and TOC, ATP, and CFU reduction after standard plant cleaning procedure in full-scale and laboratoryscale test cell at location I.

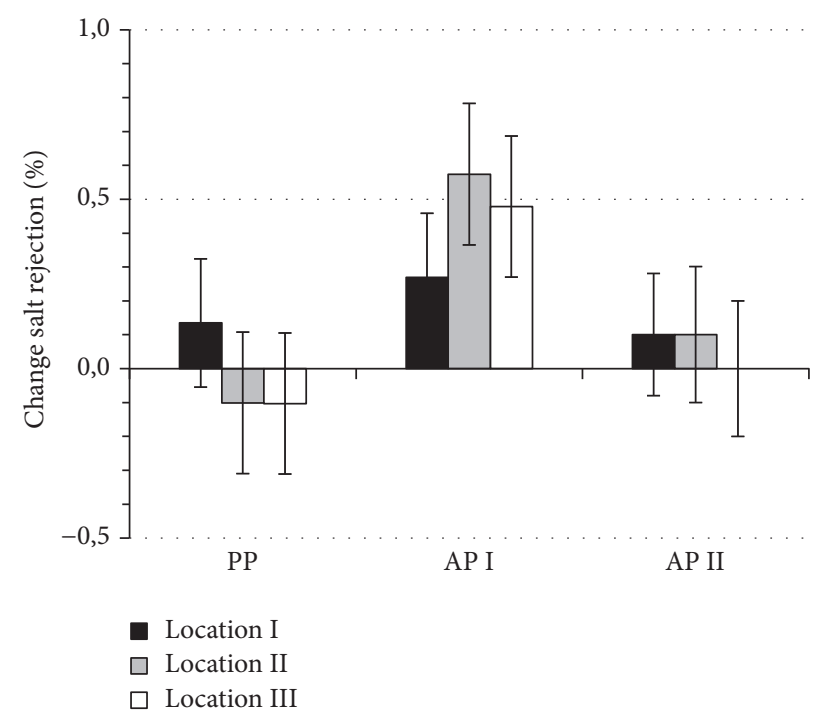

FIGURE 7: Change in salt rejection after standard plant cleaning procedure (PP) and two adapted cleaning procedures (AP I and AP II) for membrane and spacer samples from locations I, II, and III. Chemical cleaning of full-scale fouled membrane elements was performed in laboratory test cell; error bars represent standard deviation $(n=2)$.

ATP removal (79\%, 47\%, and 32\% for locations I, II, and III, resp. (Figure 8)). In general, ATP removal was high (about 90-99\%) for plant procedures and AP II, which is in accordance with CFU counts, which were zero after all CIPs applied (data not shown). As only a very small portion of the microbial diversity can be recovered on agar plates, CFU counts are only a rough estimation of biological activity. Location II showed the highest ATP concentrations before cleaning $\left(523 \mathrm{pg} \mathrm{cm}^{-2}\right)$ and the highest CFU count $2.8 \times$ $10^{5} \mathrm{~cm}^{-2}$ (Figure 5), while ATP removal using AP I was $79 \%$. The plant procedures and AP II were more effective in reducing the ATP levels (91-99\%) when compared to alternative procedure AP I (Figure 8). Location I showed the highest TOC values during autopsies $\left(45.5 \mu \mathrm{g} \mathrm{cm}^{-2}\right)$, which were approximately double of locations II $\left(22.6 \mu \mathrm{g} \mathrm{cm}^{-2}\right)$ and III $\left(22 \mu \mathrm{g} \mathrm{cm}^{-2}\right)$ (Figure 5). The highest TOC removal in location I was achieved with AP I ( 40\%) (Figure 8), which reduced already low ATP concentrations $\left(127 \mathrm{pg} \mathrm{cm}^{-2}\right)$.

The data suggests that the $\mathrm{NaOH}$ cleaning step, which is included in all cleaning procedures except AP I, leads to high removal of ATP in the plant procedures and AP II. The lower ATP removal efficiencies may be further related to the production of catalases in the biofilms, rendering peroxidebased treatments ineffective.

In general, around 20\% (Figure 8) higher TOC removal could be achieved with AP I when compared to AP II. CIP procedure AP I includes EDTA in the enzymatic blend cleaner. EDTA is a chelating agent that destabilizes EPS like structures, such as alginate, by a ligand-exchange reaction between EDTA and complexed divalent cations in EPS-like structures [10]. The usage of EDTA and proteases in AP I may explain the better (bio)organic fouling removal when compared to AP II. Overall, best cleaning results in terms of TOC removal were achieved for location III, followed by location II and location I, irrespective of the cleaning procedures applied (Figure 8). This indicates that fouling was most resistant to cleaning efforts in location I, which also had the highest initial TOC concentrations measured (Figure 5).

3.5.3. Performance Parameters ( $K_{w}$ and FCP) before and after Laboratory-Scale Cleaning. Figure 9 shows $K_{w}$ and FCP improvements after laboratory cleaning with all cleaning procedures applied. Performance improvements after chemical cleaning of the aged and persistent fouling layers were generally very low, with the highest permeability increase of $5 \%$ for AP II at location III and the highest FCP reduction of $\sim 17 \%$ for AP I at location I (Figure 9).

The observations do not seem to match with the (bio)organic foulant removal reported in Figure 8. With an average TOC removal of approximately $45 \%$, some improvement in membrane performance $\left(K_{w}\right.$ and FCP) for all three 

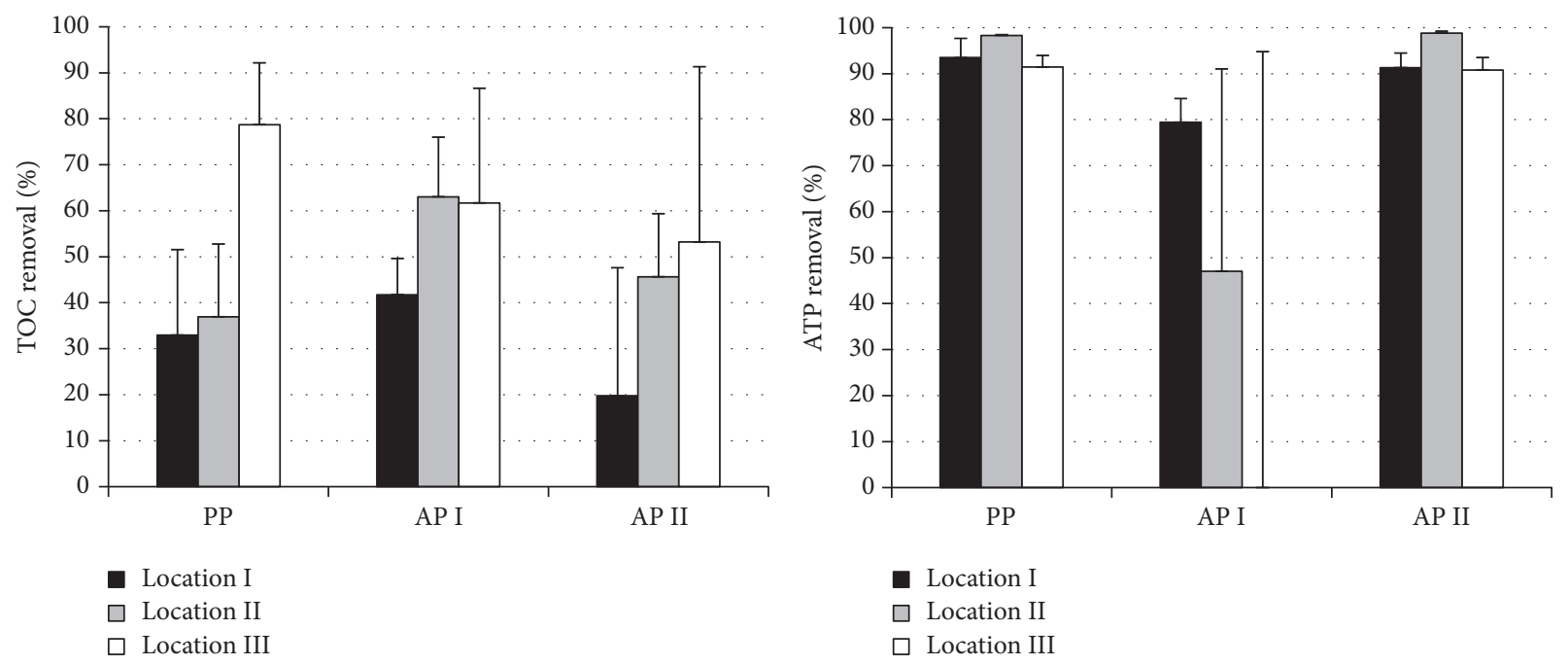

FIGURE 8: TOC and ATP removal after standard plant cleaning procedure (PP) and two adapted cleaning procedures (AP I and AP II) for membrane and spacer samples from locations I, II, and III. Chemical cleaning of full-scale fouled membrane elements was performed in laboratory test cell; error bars represent standard deviation $(n=2)$.
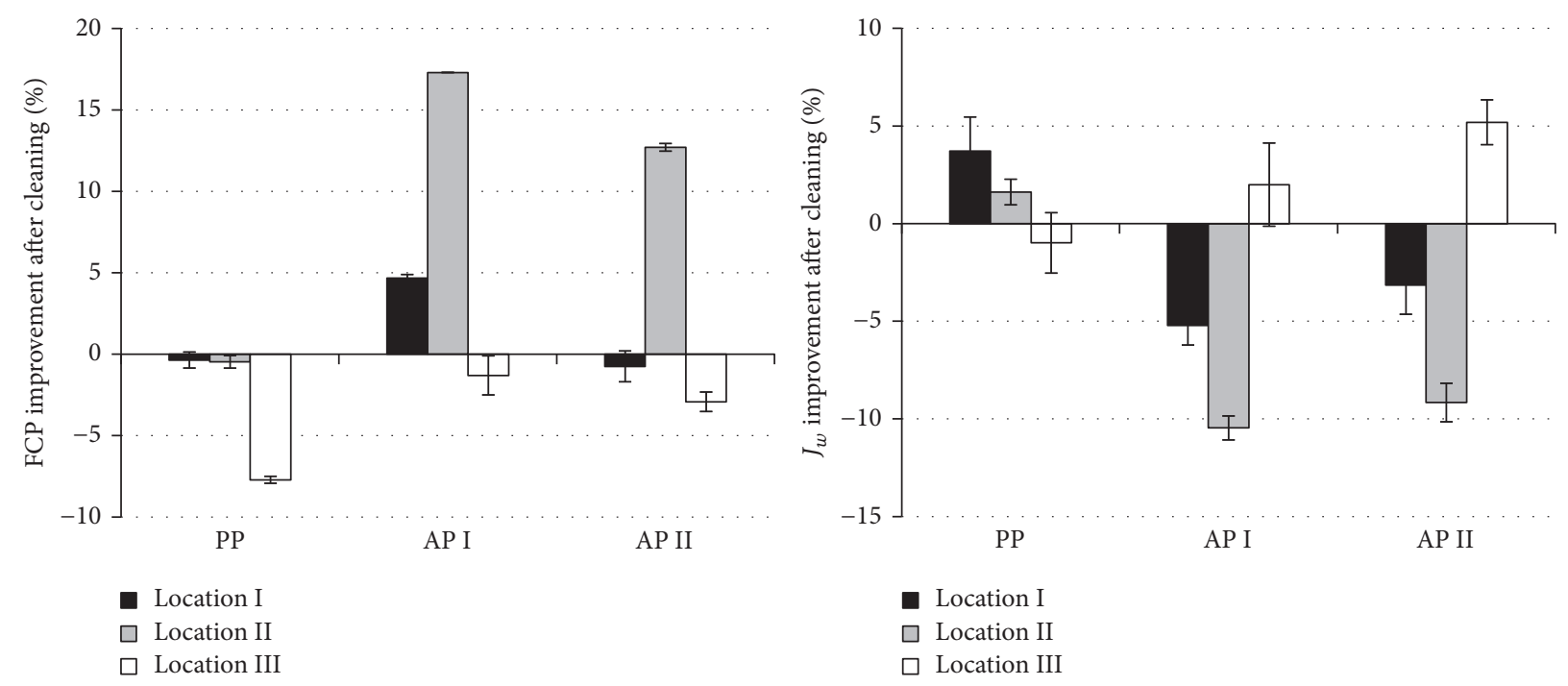

FIGURE 9: Normalized permeability $\left(K_{w}\right)$ and FCP improvements after laboratory cleaning with standard plant cleaning procedure and the two adapted cleaning procedures for membrane and spacer samples from locations I, II, and III; error bars represent standard deviation $(n=2)$.

locations was expected. At location II, the procedures AP I and AP II caused FCP increase in combination with $K_{w}$ decrease, which could be a sign of compaction of bio(organic) fouling layers. A similar effect was observed for location I and AP I (Figure 9). However, the low performance improvements of the plant procedures (Figure 9) match with the general low CIP efficiencies observed at the respective locations during the winter months, when the autopsies were performed (Figures 1-3). The aged and persistent remainders of unsuccessful CIPs (Figures 1-3) were also not effectively removed using the two alternative cleaning procedures (AP I and II).

There are temporal or permanent interactions of cleaners with the fouling layers and membrane material itself. Contact with chemical cleaners influences membrane properties such as surface charge, porosity, or hydrophobicity and thereby may also influence operational parameters such as $K_{w}$ and salt rejection. In general, chemical cleaning at high $\mathrm{pH}$ may cause membrane swelling, while cleaning at low $\mathrm{pH}$ may cause membrane shrinking [28].

Therefore, $J_{w}$ or $K_{w}$ measurements taken shortly after chemical cleaning must be evaluated with care. Furthermore, the test cell used in this study has very small spatial dimensions compared to full-scale 8-inch spiral-wound membrane elements, giving some limitation in accuracy and representativeness. Biomass removal (Figure 8), in contrast to performance increase, therefore might be the more suitable parameter for laboratory-scale cleaning efficiency comparison tests. 

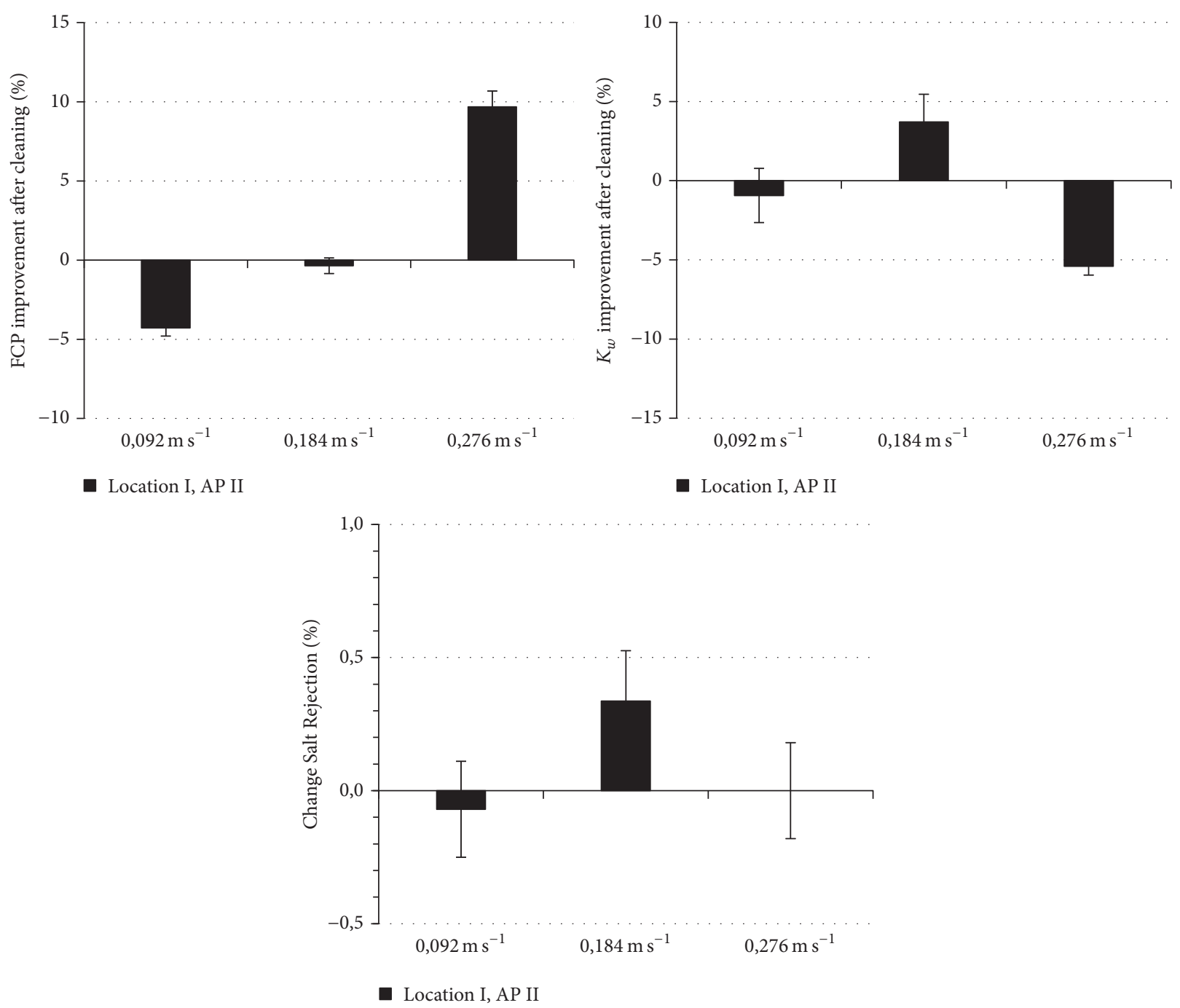

FIGURE 10: Normalized permeability, FCP, and salt rejection improvements after laboratory cleaning with AP II cleaning procedure for membrane and spacer samples from location I; error bars represent standard deviation $(n=2)$.

3.5.4. Effect of Hydraulic Forces on CIP Efficiency at Laboratory Scale. Shear stress (hydraulic forces) is an important factor in CIP. Typically, CIP is performed at high velocity to facilitate foulant removal by high shear forces and at low pressure to prevent fouling layer compaction. For the shortest of the alternative cleaning procedures (AP II), cleaning efficiencies were compared between standard velocity $\left(0.184 \mathrm{~m} \mathrm{~s}^{-1}\right), 50 \%$ increased velocity $\left(0,092 \mathrm{~m} \mathrm{~s}^{-1}\right)$, and $50 \%$ decreased velocity $\left(0.267 \mathrm{~m} \mathrm{~s}^{-1}\right)$ for location I (Figure 10).

Lowest cleaning efficiency (FCP increased 4\%; $K_{w}$ decreased 1\%) was observed for the lowest velocity (Figure 10$)$. For the standard velocity $\left(0.184 \mathrm{~m} \mathrm{~s}^{-1}\right)$, a slight improvement in permeability (4\%) and salt rejection $(0.3 \%)$ could be observed, while FCP remained unchanged. For the highest velocity $\left(0.276 \mathrm{~m} \mathrm{~s}^{-1}\right)$, FCP improved by $10 \%$, but this comes together with a $K_{w}$ decrease $(5 \%)$ at unchanged salt rejection, indicating compaction of the fouling layer. After all, none of the conditions applied was able to overcome the fouling of aged and persistent (bio)organic remainders from earlier unsuccessful CIPs (Figures 8-10). Higher velocities are generally believed to give better cleaning results, but maximum allowable cleaning solution velocity is limited by the maximum permitted NPD, especially at locations with strong NPD problems. To prevent spacer displacement within the membrane elements (telescoping), the maximum permitted NPD is 1 bar for a single element or 3.4 bar for one pressure vessel (typically containing 6-7 membrane elements) (Supplementary Table S4).

\section{Outlook}

CIP is inevitable for membrane industry, as all membranes will eventually foul. Costs for membrane element cleaning can add up to $50 \%$ of all RO operational costs [29].

Although some of the factors affecting cleaning efficiency (e.g., $\mathrm{pH}$ or temperature) were not directly investigated in this study, the adapted cleaning procedures developed (Table 3), as well as the standard cleaning procedures (Table 2), were already performed at optimized conditions (based on 
literature data such as $[10,11,16])$. The CIPs were performed tightly at the permitted limits of the membrane manufacturer in terms of cleaning solution type, concentration, temperature, $\mathrm{pH}$, and velocity (Tables 2 and 3 and Supplementary Table S4). A laboratory cleaning trial with increased shear did not lead to overall performance improvements (Figure 10). It seems that the feed spacer material in spiral-wound membranes limits the efficiency of foulant removal [23]. After all, optimizing the cleaning conditions such as temperature, $\mathrm{pH}$, cleaning duration, and velocity can only lead to increased CIP efficiencies, if there is a favorable chemical reaction between the foulant and the cleaner.

CIP remains one of the major bottlenecks in the stable operation of full-scale RO plants. Therefore, the avoidance of biofouling is a very important factor in an effective fouling prevention and control approach. Biofouling prevention may be achieved by application of excessive pretreatment or usage of biocides. However, the only biocidal active substances that are formally approved by the majority of RO manufacturers are limited to 2,2-dibromo3-nitrilopropionamide (DBNPA) and chloromethyliosothizolone/methylisothiazolone (CMIT/MIT). Biocides, as well as cleaning chemicals, must be fully compatible with all materials of an RO element. When applied as slug dosage, the biocides must also be fast acting. Broadband biocides with biofilm dispersing properties (e.g., chlorine dioxide) may be promising alternatives but have no formal approval from the membrane manufacturers.

Research on membrane fouling and chemical cleaning should strongly address harsh, aged, and persistent (composite) fouling layers, as typically found in full-scale installations. Alternative approaches to classical CIP, such as two-phase cleaning [30], should be deeper investigated and approved by the membrane manufacturers, as it is believed that the combination of chemical cleaning and mechanical cleaning improves CIP efficiencies. Research and development should furthermore concentrate on improvements in membrane element construction (e.g., allowing better fouling removal and lowering the impact of fouling on key performance parameters) and RO membranes with improved chemical resistance to (non-) oxidizing biocides and other chemical active substances used for fouling prevention and control.

\section{Conclusions}

Although different in feed water quality, design, operation, and chemical treatment, the three RO plants investigated had similar operational problems caused by aged and persistent (bio)organic fouling layers.

Traditional acid-base CIPs failed to fully restore RO performance and to remove all deposits from the membrane elements.

Comparative cleaning experiments performed in a laboratory setup showed that, even with the use of specialized bio(organic) fouling specific CIP procedures, the aged and persistent (bio)organic fouling layers were not fully removed from the membrane and spacer surfaces.

Cross-flow cells can be a useful tool for comparative testing of cleaning chemicals and CIP procedures, as they offer a good representation of the complex physical interactions during CIP. The laboratory setup can be used to access important CIP benchmark parameters such as foulant removal or membrane integrity.

Some limitations in transferring laboratory-scale data into full-scale data were unveiled and, therefore, a critical evaluation of the setup employed should be part of every study presented in literature.

The relatively low cleaning efficiencies achieved in this study were attributed to the membrane fouling history. The persistency of the aged fouling layers towards CIP in this study matches with the findings of other authors $[7,16,17]$.

\section{Disclosure}

This work was performed at Wetsus, European Centre of Excellence for Sustainable Water Technology (https://www .wetsus.nl/). Wetsus is funded by the Dutch Ministry of Economic Affairs, the European Union European Regional Development Fund, the Province of Fryslân, the city of Leeuwarden, and by the EZ-KOMPAS Program of the "Samenwerkingsverband Noord-Nederland."

\section{Conflicts of Interest}

The authors declare that there are no conflicts of interest regarding the publication of this paper.

\section{Acknowledgments}

The authors would like to thank the participants of the research theme "Biofouling" for the fruitful discussions and their financial support. In particular, they would like to thank the water companies Evides and Waterlaboratorium Noord for the possibility to perform the research presented in this manuscript at their RO locations. They are grateful to Wilbert van den Broek (Evides), Martin Pot (Evides), and Reinder de Valk (Waterlaboratorium Noord) for supplying the fullscale operational performance data and the fouled membrane elements used in this study. The authors furthermore would like to thank Dolf van der Berg (Ecolab) for helping with the development of the adapted cleaning procedures and for supplying the chemical cleaners used in this study.

\section{References}

[1] D. H. Paul, "Reverse osmosis: scaling, fouling \& chemical attack," Desalination Water Reuse, vol. 1, pp. 8-11, 1991.

[2] H.-C. Flemming, G. Schaule, T. Griebe, J. Schmitt, and A. Tamachkiarowa, "Biofouling - the achilles heel of membrane processes," Desalination, vol. 113, no. 2-3, pp. 215-225, 1997.

[3] N. Penña, S. Gallego, F. del Vigo, and S. P. Chesters, "Evaluating impact of fouling on reverse osmosis membranes performance," Desalination and Water Treatment, vol. 51, no. 4-6, pp. 958-968, 2013.

[4] M. M. Nederlof, J. C. Kruithof, J. S. Taylor, D. Van Der Kooij, and J. C. Schippers, "Comparison of NF/RO membrane performance in integrated membrane systems," Desalination, vol. 131, no. 1-3, pp. 257-269, 2000. 
[5] H. Huiting, J. W. N. M. Kappelhof, and T. G. J. Bosklopper, "Operation of NF/RO plants: From reactive to proactive," Desalination, vol. 139, no. 1-3, pp. 183-189, 2001.

[6] J. S. Vrouwenvelder, F. Beyer, K. Dahmani et al., "Phosphate limitation to control biofouling," Water Research, vol. 44, no. 11, pp. 3454-3466, 2010.

[7] F. Beyer, B. M. Rietman, A. Zwijnenburg et al., "Long-term performance and fouling analysis of full-scale direct nanofiltration (NF) installations treating anoxic groundwater," Journal of Membrane Science, vol. 468, pp. 339-348, 2014.

[8] H. S. Vrouwenvelder, J. A. M. Van Paassen, H. C. Folmer, J. A. M. H. Hofman, M. M. Nederlof, and D. Van Der Kooij, "Biofouling of membranes for drinking water production," Desalination, vol. 118, no. 1-3, pp. 157-166, 1998.

[9] J. P. Chen, S. L. Kim, and Y. P. Ting, "Optimization of membrane physical and chemical cleaning by a statistically designed approach," Journal of Membrane Science, vol. 219, no. 1-2, pp. 2745, 2003.

[10] W. S. Ang, S. Lee, and M. Elimelech, "Chemical and physical aspects of cleaning of organic-fouled reverse osmosis membranes," Journal of Membrane Science, vol. 272, no. 1-2, pp. 198210, 2006.

[11] B. Garcia-Fayos, J. M. Arnal, A. Gimenez, S. Alvarez-Blanco, and M. Sancho, "Static cleaning tests as the first step to optimize RO membranes cleaning procedure," Desalination and Water Treatment, vol. 55, no. 12, pp. 3380-3390, 2015.

[12] W. S. Ang, A. Tiraferri, K. L. Chen, and M. Elimelech, "Fouling and cleaning of RO membranes fouled by mixtures of organic foulants simulating wastewater effluent," Journal of Membrane Science, vol. 376, no. 1-2, pp. 196-206, 2011.

[13] Y. Mo, J. Chen, W. Xue, and X. Huang, "Chemical cleaning of nanofiltration membrane filtrating the effluent from a membrane bioreactor," Separation and Purification Technology, vol. 75, no. 3, pp. 407-414, 2010.

[14] E. Linley, S. P. Denyer, G. McDonnell, C. Simons, and J.Y. Maillard, "Use of hydrogen peroxide as a biocide: New consideration of its mechanisms of biocidal action," Journal of Antimicrobial Chemotherapy, vol. 67, no. 7, Article ID dks129, pp. 1589-1596, 2012.

[15] C. Liu, S. Caothien, J. Hayes, T. Caohuy, and T. Otoyo, "Membrane cleaning: from art to science," in Proceedings of the Proceedings AWWA Membrane Technology Conference, San Antonio TX, USA, March 4-7, 2001.

[16] C. zum Kolk, W. Hater, and N. Kempken, "Cleaning of reverse osmosis membranes," Desalination and Water Treatment, vol. 51, no. 1-3, pp. 343-351, 2013.

[17] K. R. Goode, K. Asteriadou, P. T. Robbins, and P. J. Fryer, "Fouling and cleaning studies in the food and beverage industry classified by cleaning type," Comprehensive Reviews in Food Science and Food Safety, vol. 12, no. 2, pp. 121-143, 2013.

[18] R. Liikanen, J. Yli-Kuivila, and R. Laukkanen, "Efficiency of various chemical cleanings for nanofiltration membrane fouled by conventionally-treated surface water," Journal of Membrane Science, vol. 195, no. 2, pp. 265-276, 2002.

[19] H. Huiting, M. de Koning, and E. F. Beerendonk, "Normalisatie van gegevens bij nanofiltratie en omgekeerde osmose," KiwaVEWIN, SWI 99.166, 1999.

[20] L. A. Bereschenko, A. J. M. Stams, G. H. J. Heilig, G. J. W. Euverink, M. M. Nederlof, and M. C. M. Van Loosdrecht, "Investigation of microbial communities on reverse osmosis membranes used for process water production," Water Science and Technology, vol. 55, no. 8-9, pp. 181-190, 2007.
[21] L. A. Bereschenko, G. H. J. Heilig, M. M. Nederlof, M. C. M. Van Loosdrecht, A. J. M. Stams, and G. J. W. Euverink, "Molecular characterization of the bacterial communities in the different compartments of a full-scale reverse-osmosis water purification plant," Applied and Environmental Microbiology, vol. 74, no. 17, pp. 5297-5304, 2008.

[22] L. A. Bereschenko, A. J. M. Stams, G. J. W. Euverink, and M. C. M. Van Loosdrecht, "Biofilm formation on reverse osmosis membranes is initiated and dominated by Sphingomonas spp," Applied and Environmental Microbiology, vol. 76, no. 8, pp. 2623-2632, 2010.

[23] L. A. Bereschenko, H. Prummel, G. J. W. Euverink, A. J. M. Stams, and M. C. M. van Loosdrecht, "Effect of conventional chemical treatment on the microbial population in a biofouling layer of reverse osmosis systems," Water Research, vol. 45, no. 2, pp. 405-416, 2011.

[24] C. Dreszer, J. S. Vrouwenvelder, A. H. Paulitsch-Fuchs, A. Zwijnenburg, J. C. Kruithof, and H.-C. Flemming, "Hydraulic resistance of biofilms," Journal of Membrane Science, vol. 429, pp. 436-447, 2013.

[25] J. S. Vrouwenvelder and D. van der Kooij, "Diagnosis of fouling problems of NF and RO membrane installations by a quick scan," Desalination, vol. 153, no. 1-3, pp. 121-124, 2003.

[26] J. S. Vrouwenvelder, S. A. Manolarakis, J. P. van der Hoek et al., "Quantitative biofouling diagnosis in full scale nanofiltration and reverse osmosis installations," Water Research, vol. 42, no. 19, pp. 4856-4868, 2008.

[27] E. Filloux, J. Wang, M. Pidou, W. Gernjak, and Z. Yuan, "Biofouling and scaling control of reverse osmosis membrane using one-step cleaning-potential of acidified nitrite solution as an agent," Journal of Membrane Science, vol. 495, pp. 276-283, 2015.

[28] A. Simon, W. E. Price, and L. D. Nghiem, "Impact of chemical cleaning on the nanofiltration of pharmaceutically active compounds (PhACs): The role of cleaning temperature," Journal of the Taiwan Institute of Chemical Engineers, vol. 44, no. 5, pp. 713-723, 2013.

[29] H. F. Ridgway, "Biological fouling of separation membranes used in water treatment applications," in AWWA Research Foundation, Denver, CO, 2003.

[30] Y. Wibisono, K. E. El Obied, E. R. Cornelissen, A. J. B. Kemperman, and K. Nijmeijer, "Biofouling removal in spiralwound nanofiltration elements using two-phase flow cleaning," Journal of Membrane Science, vol. 475, pp. 131-146, 2015. 


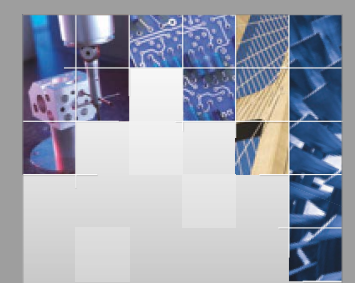

\section{Enfincering}
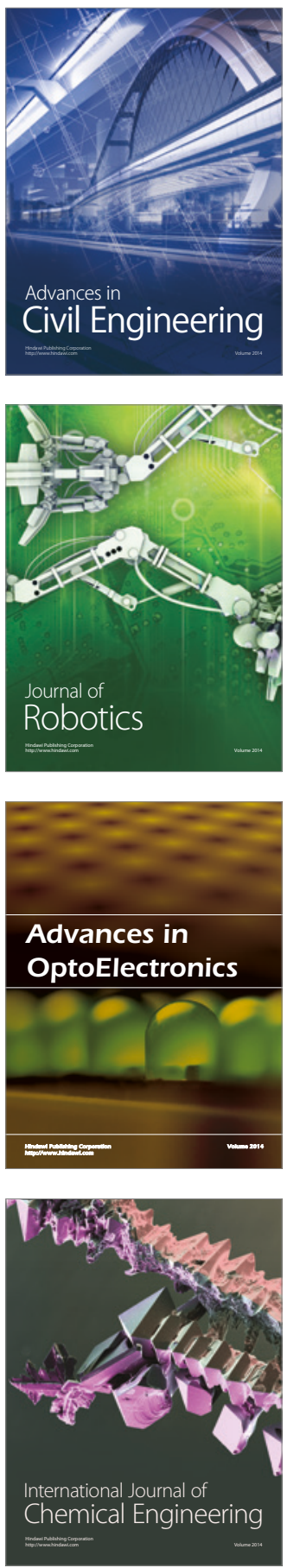

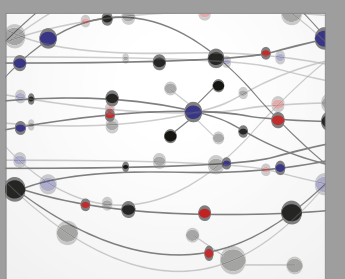

The Scientific World Journal

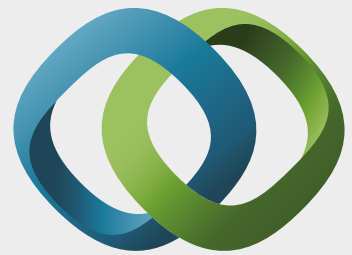

\section{Hindawi}

Submit your manuscripts at

https://www.hindawi.com
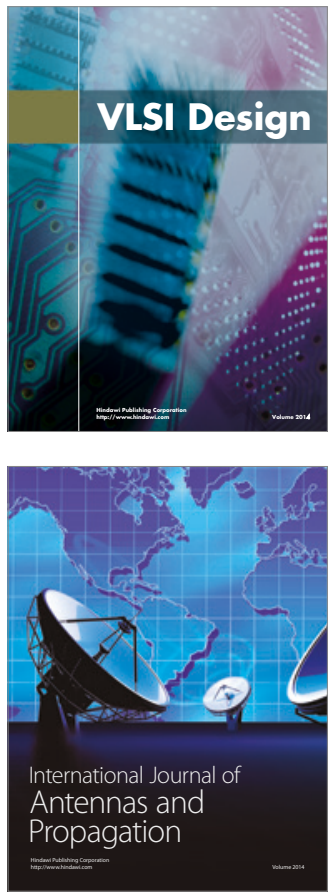

\section{Rotating}

Machinery
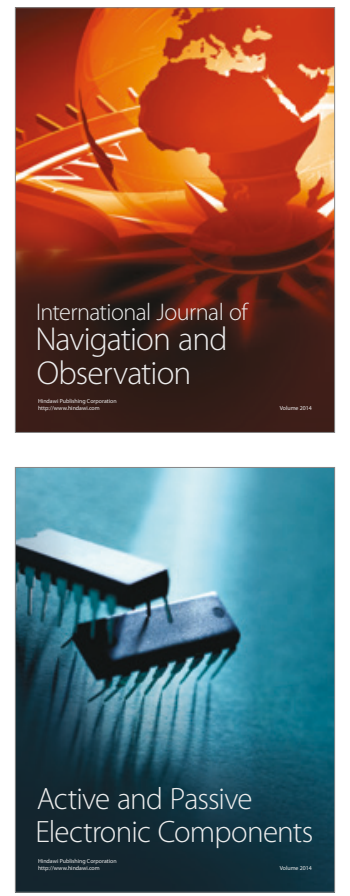
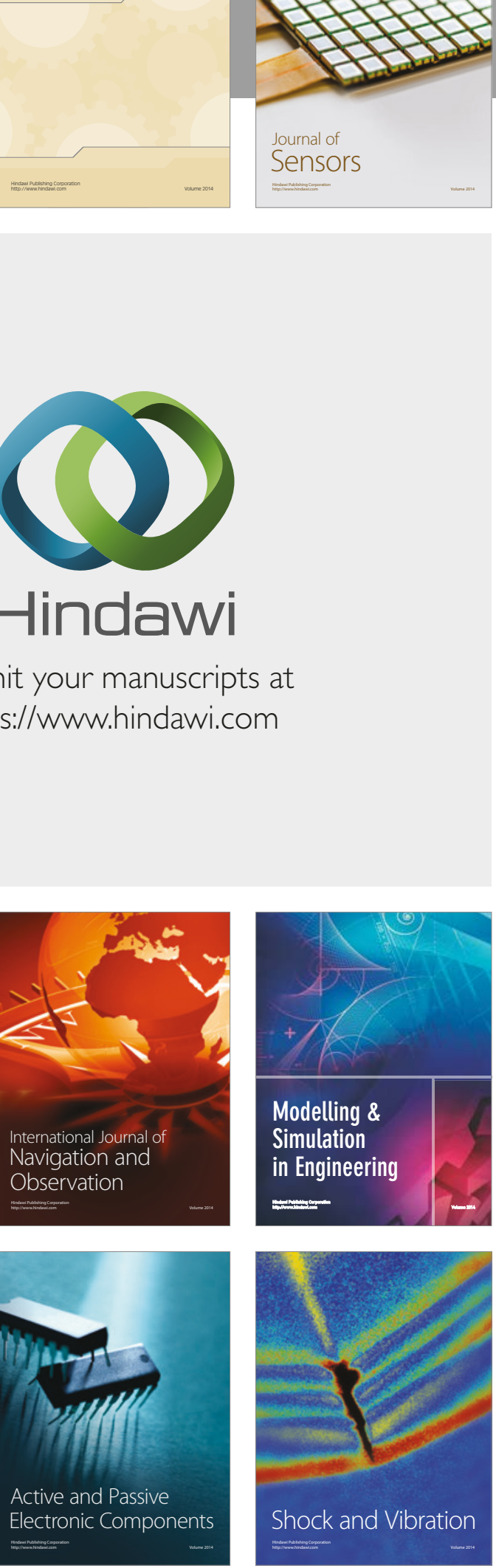
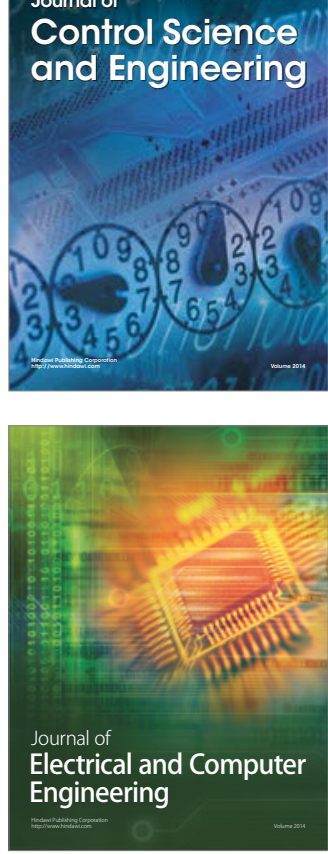

Distributed

Journal of

Control Science

and Engineering
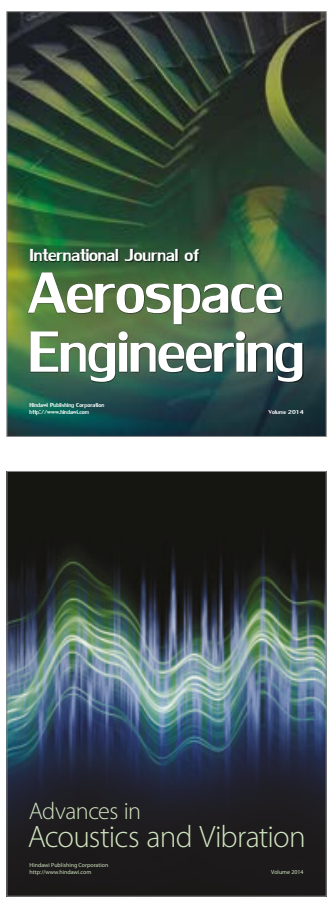

Sensor Networks 